\title{
PENDIDIKAN DASAR \\ DALAM ERA REFORMASI DAN OTONOMI
}

\author{
Oleh: \\ Drs. Aceng Jaelani, M.Ag* \\ *Dosen Jurusan PGMI FITK IAIN Syekh Nurjati Cirebon \\ Email:acengjaelani9@gmail.com
}

\begin{abstract}
ABSTRAK
Inovasi dalam dunia pendidikan tentunya akan selalu diperbarui terusmenerus baik dari segi administrasi hingga mutu peserta didik disekolah tersebut agar mampu bersaing dengan perkembangan yang terjadi di zaman teknologi. Perencanaan yang dilakukan terhadap sistem tentunya akan memberikan ekspektasi yang besar dan perubahan serta gejolak kebutuhan yang beragam, aspirasi dan kebutuhan itu sendiri yang nantinya dapat membentuk suatu gagasan dan ide baik secara otonomi dan reformasi yang akan dilakukan kaitannya dalam hal ini adalah sektor pendidikan yang nantinya membangun suatu citra dan karakter bangsa yang menjadikan warga masyarakatnya berkreatifitas dalam mengembangkan paradigma baru yang berlandaskan sistem otonomi yang disesuaikan oleh daerah itu sendiri dan tidak serta selalu bersifat adiktif terhadap keputuasan-keputusan atau kebijakan yang ditentukan oleh pusat (sentralisasi), kini kebijakan yang akan diambil dan dilaksanakan dapat dimiliki oleh setiap otonomi pendidikan yang menginginkan pembaruan yang sesuai dengan kebutuhan yang dibutuhkan dan tidak melanggar batasan-batasan yang telah ditentukan pula secara sentralisasi.

Isu-isu pendidikan yang paparkan ini memiliki kata kunci otonomi dan reformasi pendidikan yang akan kita bahas tentang bagaimana pemahaman baik itu otonomi dan reformasi serta memberikan contoh isu yang akan kita angkat dalam kajian ini tentunya berhubungan dengan otonomi dan reformasi yang akan dijalankan di dunia pendidikan.
\end{abstract}

Keyword : Otonomi, Reformasi pendidikan, Sentralisasi

\section{A. PENDAHULUAN}

'Pendidikan dasar tidak dapat kita abaikan dan dipandang sebelah mata hanya karena sebutan yang melekat padanya yaitu "dasar". Justru sebaliknya, segala sesuatu yang tidak dipersiapkan pada saat awal maka hasil yang akan dicapai tidak akan maksimal dan ajeg sesuai denganharapan. Demikian juga dalam pendidikan, pendidikan dasar akan menjadi "modal" keberhasilan 
pendidikan tahap-tahap berikutnya. Keberhasilan pendidikan pada saat awal (baca : dasar) akan mendukung keberhasilan-keberhasilan pendidikan pada tingkat berikutnya. Oleh karena itu, pendidikan dasar harus menjadi fokus perbaikan dan peningkatan kualitas ataupun kuantitasnya.

Sistem pendidikan yang selama ini dikelola dalam suatu iklim pendidikan biroratik dan sentralistik dianggap sebagai salah satu kausalitas yang menjadikannya sebab lambannya mutu pendidikan yang diperoleh. Persaingan yang menjadikan tuntutan diera globalisasi ini akan memberikan segala perubahan serta perkembangan yang pesat bagi seluruh pelaku dunia pendidikan dan di luar dunia pendidikan agar mampu bersaing, bertahan dan berkembang dari sega aspek dan sudut yang berpotensi. Inovasi yang diciptakan merupakan faktor penentu, dimulai dari hal pengambilan keputusan kebijakan baik sentralisasi dan desentralisasi atau otonomi itu sendiri didalam suatu instasi serta reformasi (pembaruan) yang sesuai dengan tuntutan kebutuhan manusia dengan mempertimbangkan perubahan yang terjadi.

Pemahaman kita sebagai calon pendidik tentunya di tuntut untuk memahami segala paradigma yang berkembang baik dari segi planning yang akan direncanakan hingga kebijakan suatu keputusan yang tentunya dilatar belakangi tujuan reformasi yang lebih baik untuk pendidikan di negara yang multi kultural ini.

Inovasi dalam dunia pendidikan tentunya akan selalu diperbarui terusmenerus baik dari segi administrasi hingga mutu peserta didik disekolah tersebut agar mampu bersaing dengan perkembangan yang terjadi di zaman teknologi. Perencanaan yang dilakukan terhadap sistem tentunya akan memberikan ekspektasi yang besar dan perubahan serta gejolak kebutuhan yang beragam, aspirasi dan kebutuhan itu sendiri yang nantinya dapat membentuk suatu gagasan dan ide baik secara otonomi dan reformasi yang akan dilakukan kaitannya dalam hal ini adalah sektor pendidikan yang nantinya membangun suatu citra dan karakter bangsa yang menjadikan warga masyarakatnya berkreatifitas dalam mengembangkan paradigma baru yang berlandaskan sistem otonomi yang disesuaikan oleh daerah itu sendiri dan tidak serta selalu bersifat adiktif terhadap 
keputuasan-keputusan atau kebijakan yang ditentukan oleh pusat (sentralisasi), kini kebijakan yang akan diambil dan dilaksanakan dapat dimiliki oleh setiap otonomi pendidikan yang menginginkan pembaruan yang sesuai dengan kebutuhan yang dibutuhkan dan tidak melanggar batasan-batasan yang telah ditentukan pula secara sentralisasi.

Isu-isu pendidikan yang paparkan ini memiliki kata kunci otonomi dan reformasi pendidikan yang akan kita bahas tentang bagaimana pemahaman baik itu otonomi dan reformasi serta memberikan contoh isu yang akan kita angkat dalam makalah ini tentunya berhubungan dengan otonomi dan reformasi yang akan dijalankan di duni pendidikan. Meskipun berbicara secara umum pendidikan, akan tetapi karena pendidikan itu dimulai dari sejak pendidikan dasar, maka urgensi judul ini termasuk di dalamnya berbicara tentang pendidikan dasar.

\section{B. PEMBAHASAN}

\section{Pengertian Otonomi Pendidikan}

Otonomi atau autonomy berasal dari bahasa yunani "autos" yang berarti sendiri, dan "nomos" yang berarti hukum atau aturan. Dalam konteks etimologi otonomi diartikan sebagai "perundingan sendiri” menurut syarif shaleh, otonomi sebagai hak mengatur dan memerintahkan daerah sendiri, yang telah diberikan oleh pusat untuk daerah. ( E120212. Blogspot.com/2013/07/makalah-tentang-otonomi-pendidikan.html=1). Sedangkan menurut Ateng syarifudin mengatakan bahwa istilah otonomi mempunyai makna kebebasan dan kemandirian, tetapi bukan kemerdekaan. ( Hasbullah, 2007 : 7) Pendapat ateng syarifudin mengenai makna otonomi bahwasannya kebijakan otonomi yang diberikan ini memberikan kita suatu pemahaman tentang kebebasan otonomi yang diiringi sesuai kebutuhan daearah dan di imabangi dengan batasan yang telah ditetapkan oleh pusat agar mutu dan kualitas yang menjadi tujuan terarah secara efektif, efesien, serta kemandirian yang dibangun disetiap daearah dengan adanya kebijakan otonomi yang diberikan. 
Otonomi pendidikan menurut UU Sistem Pendidikan Nasional No.20 adalah Tahun 2003 terungkap pada hak dan kewajiban warga negara, orangtua, masyarakat dan pemerintah. Masyarakat berhak berperan serta dalam perencanaan, pelaksanaan, pengawasan, dan program evaluasi pendidikan. Otonomi pendidikan berarti memberikan suatu otonomi dalam fungsi manajemen pendidikan kelembagaan. Otonomi disini maksudnya yaitu memberikan suatu kewenangan terhadap suatu lembaga pendidikan dengan tujuan untuk memandirikan lembaga pendidikan tersebut. Dalam otonomi pendidikan terdapat istilah manajemen berbasis sekolah dan pendidikan berbasis masyarakat. Manajemen berbasis sekolah adalah sistem manajemen yang bertumpu pada situasi dan kondisi serta kebutuhan sekolah setempat. Sedangkat pendidikan berbasis masyarakat adalah pendidikan yang dikelola secara langsung oleh masyarakat, dan didasarkan atas inisiatif masyarakat, termasuk pemanfaatan segala fasilitas yang ada dalam rangka mencapai tujuan pendidikan.

\section{Tujuan Dan Manfaat Otonomi Pendidikan}

Otonomi daerah sebagaimana dijelaskan dalam UU No. 32 Tahun 2004 adalah untuk memprcepat terwujudnya kesejahteraan masyarakat melalui peningkatan pelayanan, pemberdayaan dan peran serta dimasyarakat. Di samping itu, melalui otonomi luas, daerah diharapkan mampu meningkatkan daya saing dengan memperhatikan prinsip demokrasi, pemerataan, keadilan, keistimewaan dan kekhususan serta potensi dan keaneka ragaman daerah dalam sistem negarakeasatuan republik indonesia.

Atas dasar pencapaian tujuan diatas, prinsip-prinsip yang dijadikan pedoman dalam pemberian otonomi daerah adalah sbagai berikut (penjelasan UU No. 32 Tahun 2004): prinsip otonomi daerah menggunkan prinsip otonomi seluas-luasnya dalam arti daerah diberikan kewenangan mengurusdan mengatur semua urusan pemerindah diluar yang menjadi urusan pemerintah yang ditetapkan dalam undang-undang ni. Daerah memiliki kewenangan membuat kebijakan daerah untuk memberi pelayanan, 
peningkatan peran serta, prakarsa, dn pemberdayaan masyarakat yang bertujuan pada peningkatan kesejahteraan rakyat.

Sejalan dengan prinsip tersebut dilaksanakan pula prinsip otonomi yang nyata dan bertanggung jawab. Prinsip otonomi nyata adalah suatu prinsip bahwa untuk menangani urusan pemerintah daerah dilaksanakan berdasarkan tugas, wewenang dan kewajiban yang senyatanya telah ada dan berpotensi untuk tumbuh, hidup dan berkembang sesuai dengan potensi dan ekhasan daerah. Dengan demikian isi dan jenis otonomi bagi setiap daerah tidak selalu sama dengan daerah lainnya, adapun yang dimaksud dengan otonomi yang bertanggungjawab adalah otonomi yang dalam penyelenggaraannya harus benar-benar sejalan dengan tujuan dan maksud pemberian otonomi, yang pada dasarnya untuk memberdayakan daerah meningkatkan kesejahteraan rakyat yang merupakan bagian utama dari tujuan nasional.

\section{Pengertian Refomasi Pendidikan}

Reformasi berarti perubahan untuk perbaikan dalam bidang sosial, politik, agama atau pendidikan di dalam suatu masyarakat atau negara. Perubahan yang di kehendaki dalam reformasi menimbang kesesuaian masa depan dan kebutuhan yang diperlukan dan menghentikan penyimpangna yang terjadi, sedangkan reformasi secara etimologis berasal dari kata "reformation" dengan akar kata "reform" yang secara semantik bermakna "make or become better by removing or putting right what is bad or wrong”. Reformasi merupakan bagian dari dinamika masyarakat, dalam arti bahwa perkembangan akan menyebabkan tuntutan terhadap pembaharuan dan perubahan untuk menyesuaikan diri dengan tuntutan perkembangan tersebut. Reformasi juga bermakna sebagai suatu perubahan tanpa merusak (to change without destroying) atau perubahan dengan memelihara (to change while preserving). Dalam hal ini, proses reformasi bukanlah proses perubahan yang radikal dan berlangsung dalam jangka waktu singkat, tetapi merupakan proses perubahan yang terencana dan bertahap.

(http://mobelos.blogspot.co.id/2014/02/pengertian-dan-definisi-reformasi.html) 
Pemahaman Pendidikan sendiri secara garais besar menurut UU No 20 tahun 2003 pasal 1 pendidikan adalah usaha sadar dan terencana untuk mewujudkan suasana belajar dan proses pembelajaran agar peserta didik secara akrif mengembangkan potensinya untuk memiliki kekuatan sepiritual keagamaan, pengendalian diri, kepribadian, kecerdasan, akhlak mulia, serta keterampilan yang diperlukan dirinya, masyarakat bangsa dan negara (UUD 1945)

Reformasi pendidikan disini membawa kita kepada paradigma baru tentang pemahaman pembaruan dalam hal pendidikan baik sistem yang dilaksanakan serta pembelajaran yang bertujuan untuk mengembangkan potensi setiap pelaku pendidikan kepada arah yang lebih baik. Reformasi pendidikan perlu dilakukan dalam upaya meningkatkan kualitas pendidikan. Reformasi berarti perubahan radikal dalam upaya untu perbaikan dalam bidang sosial, politik atau agama dalam suatu masyarakat atau Negara.

\section{Tujuan Dan Manfaat Reformasi Pendidikan}

1) Tujuan

a) Secara aspek sistem pembelajaran yang dirancang kemdiknas tentang reformasi pendidikan meliputi ketersediaan, keterjangkauan, kualitas dan relevansi, kesetaraan dan kepastian.

b) Pendidikan yang diselenggarakan lebih efektif

c) Mengupayakan pembangunan pendidikan nasional baik sistem, sarana dan prasarana pendidikan

d) Pembaruan kurikulum dalam pendidikan nasional

e) Menata kmbali seluruh struktur kenegaraan, termasuk perundangan dan konstitusi yang menyimpang dari arah perjuangan dan cita-cita seluruh masyarakat bangsa.

f) Melakukan perbaikan disegenap bidang kehidupan baik politik, ekonomi sosial budaya maupun pertahanan keamanan.

g) Menghapus dan menghilangkan caracara hidup dan kebiasaan dalam masyarakat bangsa yang tidak sesuai lagi ngan tuntutan reformasi, 
sperti KKN, Kekuasaan sewenang-wenang/ otoriter, penyimpangan dan penyelewengan yang lain dan sebagainya.

2) Manfaat

a) Peningkatan mutu pendidikan

b) Peluasan dan pemerataan kesempatan mengikuti pendidikan

c) Dapat menjalankan manajemen berbasis sekolah sesuai dengan perubahan suatu daerah tersebut

\section{Contoh Isu-Isu Otonomi dan Reformasi Pendidikan}

1) Pengesahan Undang-Undang Nomor 22 Tahun 1999

Pemberlakuan undang-undang dasar ini tentang pemerintah otonomi daerah mengisyaratkan pengembangan suatu wilayah dalam suasana yang lebih kondusif dan dalam wawasan yang lebih demokratis, hal ini dapat terlihat dalam pengelolaan dan pengembangan pendidikan yang lebih bersifat desentralistik. (Syam, $2010: 1$ )

2) Ada implikasi utama dari pelaksanaan otonomi daerah bidang pendidikan, yaitu penyelenggaraan pendidikan oleh daerah-daerah dan pemberlakuan kurikulum berbasis sekolah (KTSP). Dalam hal penyelenggaraan pendidikan oleh daerah, kementrian pendidikan dan kebudayaan tidak lagi memiliki kantor wilayah di propinsi dan kantor departemen di kabupaten atau kota. Peran kantor wilayah dan kantor departemen diambil alih oleh dinas pendidikan yang menjadi bagian dari pemerintahan daerah. Implikasi lebih lanjut dari pemberlakuan hal ini adalah penyaluran anggaran pendidikan lewat pemerintah daerah, pengelolaan lembaga-lembaga pendidikan oleh daerah, dan pengelolaan tenaga pendidik dan tenaga kependidikan oleh daerah.

3) Reformasi dalam pendidikan Islam tidak terlepas dari adanya pembaharuan dan perbaikan yang merupakan perkenalan sarana untuk meningkatkan beberapa aspek dalam proses pendidikan agar terjadi perubahan secara kontras dari sebelumnya dengan maksud-maksud tertentu yang ditetapkan. Proses pendidikan merupakan sebuah sistem dimana keberhasilannya ditentukan oleh seberapa besar fungsi komponen 
pendidikan tersebut dalam merealisasikan target dari pada tujuan yang telah ditentukan. Selanjutnya, agar manusia dapat memahami segala perubahan maka ia harus dapat memahami peristiwa-peristiwa masa lalu sebagai cermin dan bahan pertimbangan dalam merumuskan harapan di masa depan. (Marlina, 2015 )

\section{SIMPULAN}

Otonomi pendidikan berarti memberikan suatu otonomi dalam fungsi manajemen pendidikan kelembagaan. Otonomi di sini maksudnya yaitu memberikan suatu kewenangan terhadap suatu lembaga pendidikan dengan tujuan untuk memandirikan lembaga pendidikan tersebut. Dengan adanya kemandirian dari sebuah lembagapendidikan berarti lembaga tersebut mempunyai kewenangan untuk menentukan program pendidikan sesuai kebutuhan serta kearifan lokal yang ada di dalam lingkungan sekitar atau daerah di mana pendidikan itu berada.

Reformasi pendidikan disini membawa kita kepada paradigma baru tentang pemahaman pembaruan dalam hal pendidikan baik sistem yang dilaksanakan serta pembelajaran yang bertujuan untuk mengembangkan potensi setiap pelaku pendidikan kepada arah yang lebih baik. Pembaharuan yang sangat mencolok dibutuhkan pada saat ini yang lebih penting adalah paradigma kita tentang pendidikan dan pengajaran itu sendiri, sehingga dengan perubahan cara pandang terhadap pendidikan akan mengarah kepada perbaikan-perbaikan dalam operasionalisasi pendidikan atau pembelajaran tersebut, seperti pada aspek metodologi dan juga penguatan konten bagi pendidik itu sendiri.

Pendidikan dasar yang menjadi salah satu komponen terpenting dalam suatu proses pendidikan, tidak terkecuali harus ikut tumbuh dan berkembang seirama dengan adanya isu reformasi daan otonomisasi pendidikan yang sedang menggelinding di era pembangaunan bangsa Indonesia dewasa ini. Pendidikan Dasar tidak bisa dipandang sebelah mata dan dianggap enteng karena yang dihadapi adalah "kanak-kanak". Bahkan pendidikan pada usia dasar ini akan menjadi fundamental yang kokoh bagai keberlanjutan pendidikan manusia berikutnya. 


\section{DAFTAR PUSTAKA}

Hasbullah. 2007. Otonomi pendidikan kebijakan otonomi daerah dan Implikasinya Terhadap Penyelenggaraan Pendidikan. Jakarta : PT Raja Grafindo Persada

Kementrerian Pendidikan Nasional , Undang-undang Nomor 20 tahun 2013 tentang Sistem Pendidikan Nasional

Marlina, Leli. 2015. REFORMASI SISTEM PENDIDIKAN ISLAM (TELAAH PEMIKIRAN HASAN AL-BANNA DAN IMPLEMENTASINYA DALAM PENDIDIKAN ISLAM). Skripsi thesis, UIN SUNAN KALIJAGA YOGYAKARTA.

Nuh, Muhammad. 2010. Reformasi Pelaksanaan sistem Pendidikan Nasional.

Syam, M.Chan. 2010. Kebijakan pendidikan era otonomi daerah. Jakarta: rajawali perss.

http://mobelos.blogspot.co.id/2014/02/pengertian-dan-definisi-reformasi.html

http://Blogspot.com/2013/07/makalah-tentang-otonomi-pendidikan.html 